\title{
REVALENCE OF CLADOSPORIUMSPORES OVER SUNFLOWER FIELDS
}

\author{
G.M. Pathare \\ Dept. of Botany, Anandrao Dhonde Alias Babaji College, Kada. Tal. Ashti, Dist. Beed. \\ E-mail. gorakshapathare14@gmail.com
}

Communicated: 27.07 .20

Revision :09.08.20 \&

25.08.2020

Accepted: 10.09 .2020

Published: 30.09 .2020

\begin{abstract}
Present paper deals with the aerobiological investigation over Sunflower fields by using Volumetric continuous Tilak Air Sampler was employed for exploring fungal airspora over a Sunflower field at Kada, Tal. Ashti and Dist. Beed. $5^{\text {th }}$ July to $30^{\text {th }}$ September 2003 for second Kharif season and $10^{\text {th }}$ November 2003 to $2^{\text {th }}$ February 2004 for first Rabi season. The present paper deals with airborne concentration of Cladosporium spores over sunflower fields. The concentration of airborne Cladosporium spores was assessed and the roles of the metrological parameters over the spore concentration were discussed. The spore concentration was maximum $\left(58030 / \mathrm{m}^{3}\right.$ and $46270 / \mathrm{m}^{3}$ of air $)$ in the month of September 2003and December2003during second Kharif season and first Rabi season respectively.
\end{abstract}

Key words: - Aerobiology, Cladosporium, Air Sampler, Sunflower field.

\section{INTRODUCTION:}

Aerobiology is an interdisciplinary science which deals with the study of biological component like pollen grains, fragments of fungal spores, hyphal fragments, bacteria, viruses, algae, lichens, minute insects \& insect parts, protonzoan cyst, etc. In the atmosphere a biotic particulates \& gases affecting living organisms have been recently included in the concept of aerobiology. The aerobiological studies are mainly concern with interrelationship between the biological component in the atmosphere, source of biological component, their release in the atmosphere, their deposition \& impact on health of plants \& animals including human beings. Airborne infections \& the resulting diseases threaten the lives \& productivity of plants. Airborne diseases still pose a challenge to mankind.

The role of fungi in causing diseases to crop plants, man, domestic animal, in bringing deterioration of food grains in storage, valuable monuments has been subject of great interest for long time. Standing vegetation has a great influence of Aerospora of any place and it changes with changes in weather. Aerobiological survey conducted in various part of India revealed richness of Aerospora.

Sunflower (Helianthus annus L.) is one of the most important oil seed crops being grown all over the world. It is mainly grown for its oil, which is generally for culinary purposes in preparation of vanaspati and in manufacture of soaps and cosmetics. The sunflower oil is chemically a tri-glyceride. It contains $68 \%$ linolic acid, so it is especially recommended for patients having heart troubles. Sunflower seed cake or meal is a protein reach feed and is used as a concentrate for cattle, animals like pig, sheep, goat and poultry feed. Sunflower is native of North America. In Germany and Russia it is grown on large scale. Now a day's sunflower crop cultivation has become more popular among the farmers of Marathwada region. As considering survey of this crop that since last few years sunflower is subjected to various type of fungal diseases which may be soil borne, seed borne, airborne etc. The aim of present study 
was to find out the atmospheric concentration of Cladosporium and its correlation with meteorological parameters. It was with the aim to find out the important airborne pathogens, their distribution and seasonal variation in the concentration these investigations were undertaken, the prediction of airborne fungal disease could be attempted. If well in advance information of airspora of this crop is made timely available. In view of the above fact using by continuous Volumetric Tilak Air Sampler carried out an aero mycological survey over sunflower field for Kharif and Rabi season.

\section{MATERAIL AND METHODS:}

In the present investigation an exploration of airborne spores of Cladosporium (Tilak and Kulkarni 1970) was undertaken over the fields of sunflower field for Kharif and Rabi season. Tilak Air Sampler was installed at a constant height of 1.5 meters above the ground level at Kada Tal. Ashti. Dist. Beed (M.S.) for one Kharif and one Rabi season i.e. 5th July 2003 to 30thSeptember 2003 for second Kharif season and $10^{\text {th }}$ November 2003 to 29th February 2004 for first Rabi season. The air was sampled at the rate of 5liters/minutes which left traces of deposition over cellophane tape, affixed on the outer surface of drum. The slides were prepared every offer eight days. Before the scanning, the slides were marked with a ball pen point pen in the six equal parts, each part, indicating the spore catch of two hours of sampling period. Area of 9600 sq.micron of the total area of the trace obtained was scanned under $10 \mathrm{Xx} 45 \mathrm{X}$ eye piece objective combination of binocular research microscope. The transformation of spore was done which was based on visual characteristics of spore such as size, shapes. The metrological data was recorded during period of investigation.

\section{RESULT AND DISCUSSION:}

The spores of Cladosporium were variable in shape and size, ovoid to cylindrical or irregular, dark sub hyaline to pale brown, one or two celled or lemon shaped. These spores were found to be the most abundant as compared to other airborne micro biota in order of their concentration and hence dominated aerial population.

The high incidence of the spores of Cladosporium in air was due to their capability of producing the spores directly on hypha and copious fruiting ability with passive mechanism of spore liberation. Besides, the gentle wind currents, natural or artificial mechanical disturbances force the spores of Cladosporium to liberate in the air in an enormous amount, as it was already suggested by Gregory (1961). The spores contributed $26.02 \%$ and $24.62 \%$ during second Kharif season first Rabi season respectively.

In second kharif season, the highest monthly concentration $\left(58030 / \mathrm{m}^{3}\right)$ was recorded in the month of September 2003, when there was record of moderate range of temperature between 21.4 to $29.7^{\circ} \mathrm{C}, 61.8$ to $92.47 \%$ relative humidity, $2.8 \mathrm{~km} / \mathrm{h}$ wind velocity and $77.5 \mathrm{~mm}$ rain fall. The day on which there was record of rain and high wind velocity, the concentration Cladosporium spores was found to be considerably reduced, which may be due to the washing effect. Nevertheless, during the second kharif season the maximum concentration $\left(6300 / \mathrm{m} 3\right.$ of air) was recorded on $9^{\text {th }}$ September 2003 , when there was record of $25.5^{\circ} \mathrm{C}$ of mean temperature, $75 \%$ relative humidity and $4.4 \mathrm{~km} / \mathrm{h}$ wind velocity. In first Rabi season the highest monthly concentration $\left(46270 \mathrm{~m}^{3}\right)$ was recorded in the month of December 2003. The maximum daily mean concentration $\left(4200 / \mathrm{m}^{3}\right)$ was recorded on 16 th December 2003. 
The spores of Cladosporium have been found to be always dominant in many parts of the world. The occurrence of these spores in large number has been recorded by Hara and Durhan (1939), Turner (1966) from Japan, Rees (1964) from Australia, DeMeena (1955) from New Zealand, Gregory and Hirst (1957), Harvey (1967), Meredith (1962) from Jamaica, West Indies. Pady (1966) recorded these spores in bulk during summer period. Sreeramulu (1962) recorded very high concentration of these spores in the month of December. Gaikwad (1974), Tilak and Vishwe (1975), Pande (1976), Mane (1978), Bhalke (1981), Shastri (1981), Bhagwan (1983), Pillai (1983), Patil (1983), Venugopalachari (1986), Ramakrishna Reddy (1987), Minhaj (1988), Meghraj (1989). Kavishwar (1990) at Dhule, reported 73.06\%. Shinde (1996) at Nanded, reported 8.47\%. Thite (1998) and Pawar (1998), Tuljaputkar (2000) and Garje (2000) also recorded these spores from airspora at Aurangabad. Mali (2002) and Banswadkar (2002) also reported these spores at Kada and Udgir respectively. Gopan (2004) and Pathare (2004) reported these spores over sunflower fields at Beed and Kada respectively. During the period of present investigation, the spores of Cladosporium were almost continuously found in the atmosphere over the sunflower field. The dominance of the spores of Cladosporium may be regarded as a universal dominant because earlier workers from India and abroad also reported this spore type as the dominant type. In air Cladosporium spores showed their clumps and hence called "Conidial units of dispersals." The high incidence of Cladosporium spore type in air was due to their high saprophytic ability. However, there spore liberation was passive. The air turbulence and mechanical disturbances were the main factors to bring about the release of enormous amount of spores, the climatic factors generally are responsible to influence the sporadic outbreak at certain disease, however during the period of present investigation did not occur. Thus, the regional climate not only determines the profitable growth of crop but also influences the dangerous of disease to which crops are proned. The relation between the development of disease and weather is the basis on which incidence and occurrence of diseases can be predicted. As matter of fact, plant disease forecasting is the natural corollary of plant disease epidemiology. These findings have clearly brought out that there was a close relationship between environmental parameters, availability of the substratum for the copious growth and the dispersal of the spores in the atmosphere.

Thus, the atmospheric microbial population in relation to phytopathology has an ample scope for further investigations. Such studies would bring many useful results like disease forecasting which would ultimately help in protecting our crop.

\section{REFERENCES:}

Aher, S.K., Thite S.V. \&Pande B.N. (2002). Fungal airspora of a groundnut field. Eco, Env. \& Cons, 8 (3): 283 -288

Aher S.K. and B.N. Pande (2004) Aerobiological approach to pathogenic fungal spores over groundnut field. Ecol. Env and Cons. 10 (1):57-59

Bhalke SP, (1981). Airspora over some fields. Ph.

D. Thesis, Marathwada University, Aurangabad.

De Meena, M.E. (1955), A quantitative study of airborne.Trans.Brit.Mycol.Soc.,38:119129

Gregory PH, 1954. The construction and use of portable volumetric spore trap. Trans. Brit. Mycol. Soc., 37: 390 - 404. 
I J R B A T, Feb 2020: 01-07

Gregory PH, 1961. The microbiology of the atmosphere. Leonard Hill (Books) Ltd. Inter Science Publishers, INC New York, 1-205.

Gregory PH, and Hirst (1957), J. Gen. Microbiol. 17:135-152

Meredith, D.S. (1962). Ann. Appl.Biol.,50:479495

Mane, D.A. (1978) Studies in airspora over some fields. Ph.D. Thesis Marathwada University, Aurangabad.
Pathare G.M. \& Mali V.P. (2008), an aerobiological survey of fungal spores in two Different seasons over sunflower fields. Life Science Bulletin, (5) 43-46.

Tilak, S.T. and Srinivasulu B.V. (1967). Ind. J. Microbiol., 7:168:170

Tilak, S.T. \&Kulkarni R.L. (1970) A new air sampler Experienta. 26: 443-444 